Slobodanka Gligorić ${ }^{1}$

Filološka gimnazija, Beograd
УДК $371.3:: 811$

DOI 10.18485/zivjez.2016.36.1.5

Прегледни рад

\title{
TEORIJE USVAJANJA JEZIKA: GENERATIVNI ILI EMERGENTISTIČKI PRISTUP
}

Jezik je univerzalna sposobnost svakog čoveka - iako ne poseduju svi ljudi isti jezik, činjenica je da svi ljudi poseduju jezik. Ovaj jedinstveni način komunikacije svojstven je našoj vrsti nekih 200.000 godina, međutim način na koji dolazi do njegovog usvajanja još uvek je misterija za nauku. Ovaj rad ima za cilj da predstavi dve suprotstavljene struje razvojne psiholingvistike: generativni pristup Noama Čomskog i emergentistički pristup zasnovan na jezičkoj upotrebi Majkla Tomazela, njihove ideje i postulate i da kroz pregled studija vezanih za ovu oblast ukaže na osnovne sličnosti i razlike između ova dva pravca. Poseban naglasak stavlja se na kritike upućene i jednoj i drugoj školi mišljenja, kao i novim teorijskim pravcima koji su nastali kao rezultat ovakvog kritičkog preispitivanja.

Ključne reči: generativni pristup, univerzalna gramatika, UB pristup, modularnost

\section{Uvod}

Jezik je univerzalija svojstvena svim ljudskim bićima - ne postoji ljudska zajednica koja ne poseduje jezik i ne postoji ljudsko biće koje nije u stanju da ga usvoji ${ }^{2}$. Ipak, mehanizam kojim se to usvajanje odvija i dalje je nepoznat. Još su se Platon i Aristotel bavili pitanjem usvajanja jezika, svodeći problematiku na dihotomiju racionalizma i empiricizma, genetike ili odgoja, usvajanja ili učenja. Više od dvadeset vekova kasnije, osnovno pitanje i dalje ostaje isto: da li se jezik usvaja ili se uči? Da li postoji genetski kod za jezik

1 slobodankagligoric@gmail.com

2 Sa izuzetkom patoloških slučajeva. 
u ljudskoj DNK ili su mehanizmi generalizacije, asocijacije i statistička svojstva jezičkog inputa odgovorni za učenje jednog ovako strukturisanog sistema?

U ovom radu predstavićemo dve najprominentnije i najčešće suprotstavljane teorije jezičkog usvajanja: generativni model Noama Čomskog i pristup zasnovan na jezičkoj upotrebi Majkla Tomazela. Posebnu pažnju posvetićemo kritikama inherentnih problema obe navedene škole mišljenja i pokušati da skiciramo poten cijalni „srednji put” između ova dva navodna ekstrema. Nove tendencije $\mathrm{u}$ istraživanju razvojne psiholingvistike navode na ideju da srž problema možda leži u načinu postavljanja pitanja: priroda ili odgoj, usvajanje ili učenje. Ukoliko prihvatimo mogućnost istovremenog postojanja oba navedena uticaja, veće su šanse da se za korak približimo odgovoru.

\section{Generativni pristup}

Generativni pristup usvajanju jezika vezuje se za objavljivanje "Sintaksičkih struktura" Noama Čomskog 1957. godine; ovaj pristup je u kratkom vremenskom roku postao dominantna struja u lingvistici XX i XXI veka, a generativističko viđenje usvajanja jezika zasnovano na ideji genetske predispozicije i univerzalne gramatike osnova brojnih novih pravaca. Jedan od osnovnih razloga njegove dominacije i kontinuiteta leži upravo u preispitivanju i revidiranju stavova u okviru generativnog pristupa kako bi se uzela u obzir najnovija jezička istraživanja. Samim tim, ne možemo govoriti o jednoj jedinstvenoj i nepromenljivoj generativnoj teoriji, već moramo uzeti u obzir čitav spektar generativnih modela.

Klasična generativna teorija usvajanja jezika javlja se kao reakcija na biheviorističko gledište po kojem je svako učenje reakcija na spoljašnji stimulus i kao takvo u direktnom odnosu sa brojem ponavljanja i konceptom nagrade, to jest kazne. Ovakvo stanovište podrazumeva da se deca rađaju bez ikakvog „pomoćnog Sistema” za savladavanje jezika - dolaze na svet sa stanjem svesti koje Lok naziva "tabula rasa” - te da jezik usvajaju istim opštim mehanizmima 
učenja koje koriste da bi naučili da vežu pertle ili da se koriste priborom za jelo. Lingvisti generativne škole, međutim, tvrde kako se jezičko znanje koje dete usvoji - takozvani I-jezik - ne može objasniti jednostavnom interakcijom opštih mehanizama učenja i jezičkog inputa kojem je dete iskustveno izloženo (Sugisaki i Otsu 2011: 291).

Nemogućnost modela stimulus/reakcija da objasni očiglednu disproporciju između ograničenog jezičkog unosa kojem su deca izložena od rođenja i bogatog jezičkog znanja koje usvoje u samo nekoliko godina navela je generativne lingviste da pretpostave kako je sposobnost usvajanja jezika svojstvena čovekovoj vrsti, te da se svako dete rađa sa urođenim mehanizmom za usvajanje jezika - takozvani Language Acquisition Device (LAD) - koji mu omogućava da produkuje i analizira teoretski neograničen broj iskaza, bez obzira na to da li se konkretni jezički materijal pojavio u inputu. Na ovaj način generativna teorija zastupa nativistički pristup i naglašava modularnu prirodu naše jezičke sposobnosti (Kerol 2008: 343). Modularnost se u ovom smislu posmatra kao postojanje zasebnih urođenih domenski specifičnih struktura (Semjuels 2000: 16) u ljudskom mozgu zaduženih isključivo za usvajanje jezika, za razliku od onih koji kontrolišu „ostale centralne aspekte ljudske kognicije" (Njuport 2011: 279). Ovi podsistemi nalik organima u ljudskom organizmu imaju svoje pojedinačne funkcije i kao takvi mogu se proučavati nezavisno jedni od drugih. Po Čomskom, jezički modul se uveliko oslanja na postojanje takozvane univerzalne gramatike (UG) koja bi trebalo da sadrži opšte važeća sintaksička pravila i principe koji nam omogućavaju da razlikujemo pravilno formirane iskaze od negramatičkih. Prema lingvistima generativne škole ovo objašnjava brzinu kojom deca usvajaju jedan toliko kompleksan sistem na relativno ranom uzrastu.

Kao jedan od glavnih dokaza urođene prirode jezika i postojanja univerzalne gramatike navodi se činjenica da su deca u stanju da usvoje jezik bez obzira na to što su u najkritičnijem periodu usvajanja izloženi veoma ograničenom uzorku. Ovo se popularno naziva „Platonov problem“ili „logički problem usvajanja jezika“. Čomski i njegovi sledbenici tvrde kako ograničen input koji ne sa- 
drži dovoljnu količinu negativnih dokaza - ispravki i reformulacija koje detetu u procesu usvajanja jezika stavljaju do znanja koji iskazi nisu gramatični - ne može da objasni detetovu jezičku kompetenciju, to jest „kapacitet [dece] da kreiraju neograničen broj [gramatičnih] rečenica i rečeničnih struktura" (Ajzenbajs 2009: 275), te da samim tim objašnjenje ovog problema mora da leži u urođenoj sposobnosti koja odvaja čoveka od životinja. Neki od lingvista generativne škole su čak išli tako daleko da postuliraju postojanje takozvanog "gena za jezik" - FOXP2 - koji bi bio glavni nosilac ove ljudske sposobnosti. Većina stručnjaka, međutim, odbacuje ovu ideju kao generalizovano idealističko pojednostavljivanje i navodi kako se brojne genetske promene koje je ljudska vrsta prošla tokom filogeneze i koje su omogućile razvoj i usvajanje jezika (fina motorika, brza obrada informacija, sposobnost inter-modularne percepcije) ne mogu svesti na jedan izolovani gen ili sistem gena, kao i da su ove genetske promene podjednako odgovorne za razvoj mehanizama nevezanih za jezik i jezičku sposobnost (Bejts u Karmilof-Smit 2005: 226) čime se dovodi u pitanje stroga modularnost klasične generativne teorije.

Insistiranje na jezičkoj modularnosti i domenski specifičnoj prirodi $L A D$-a najčešće su kritikovani argumenti generativne teorije usvajanje jezika u njenom izvornom obliku. Ideja da je jedan kognitivni proces ili jedna regija mozga namenjena isključivo usvajanju jezika izazvala je oštre kritike u stručnoj javnosti. Osim toga, postavlja se pitanje na koji način univerzalna gramatika i $L A D$ omogućavaju usvajanje pojedinačnih jezika i njima specifičnih gramatičkih obeležja. Kao reakciju na ove izazove i uzimajući u obzir nova kognitivistička istraživanja, Čomski je krajem sedamdesetih godina prošlog veka razvio novi pristup generativnoj teoriji, nazvan teorija principa i parametara (P\&P-teorija), odnosno teorija upravljanja $i$ vezivanja (UV-teorija) ${ }^{3}$.

U okviru ove teorije Čomski razvija ideju o postojanju nepromenljivih gramatičkih principa ljudskog jezika koji su urođeni svakoj jedinki i podesivih parametara preko kojih se ispoljavaju razlike

$3 \quad$ Principles and Parameters Approach (P\&P Theory), to jest Government and Binding Theory (GB Theory). 
između pojedinačnih jezika. Principi funkcionišu na približno sličan način kod svakog deteta, uz minimalni uticaj spoljašnjih faktora, dok se parametri menjaju ili podešavaju na osnovu primarnih lingvističkih podataka (PLP) kojima je dete od rođenja izloženo (Snajder i Liljo-Martin 2010: 670). Razlike između ljudskih jezika se tako objašnjavaju kao različite postavke navedenih parametara, čime ova teorija rešava pitanje usvajanja različitih jezika uz pomoć urođene Univerzalne Gramatike. Osim toga, P\&P teorija deluje kao idealan odgovor na pitanje „logičkog problema jezičkog usvajanja“. Prema ovoj teoriji, detetov zadatak nije da na osnovu uzorka koji čuje izgradi gramatiku od nule (ibidem: 671), već jednostavno da izabere kako će podesiti parametre između ponuđenih opcija. $\mathrm{Na}$ ovaj način input kojem je dete izloženo ima ulogu „okidača“ koji mu pomažu da izabere između konfliktnih (u idealnom slučaju binarnih) vrednosti podešavanja (Hajmz 2011: 14). Po rečima Snajdera i Liljo-Martinove: „detetov zadatak prilikom usvajanja jezika nalik je naručivanju hrane u restoranu: potrebno je samo izabrati [jelo] sa menija, a ne dati recept kuvaru" (Snajder i Liljo-Martin 2011: 671).

Ipak, reći da je ovom varijantom teorije generativna škola odgovorila na sve kritike i ponudila sveobuhvatnu teoriju usvajanja jezika bilo bi daleko od istine. Neki od najčešće spominjanih problema vezani su za inicijalnu postavku parametara, kao i izbor vrednosti među kojima se bira. Da li se parametri mogu opisati kako ih Čomski posmatra: kao prekidači sa malim brojem mogućih podešavanja? Da li su ovi prekidači inicijalno nepodešeni ili su pak podešeni na unapred određene vrednosti, koje se zatim menjaju u odnosu na input? Ni sam Čomski nije bio u potpunosti zadovoljan ovim pristupom, te je sredinom devedesetih godina prošlog veka još jednom bitno izmenio dotadašnju generativnu teoriju formulišući takozvani minimalistički program u kom odmerava svoje dosadašnje ideje i verovanja i odbacuje mnoga od njih kao „konceptualno nepotrebna i empirijski neadekvatna" (Čomski 1995: 375). Minimalistička teza nadovezuje se na ideje teorije principa i parametara, ogoljene do najosnovnijih elemenata. Usvajanje jezika posmatra se kao razvoj organskog sistema na koji utiču tri osnovna faktora: genetska predodređenost (nezaobilazna univerzalna gramatika), eksterni poda- 
ci (jezičko iskustvo koje funkcioniše kao „okidač” pri podešavanju parametara) i dodatni opšti principi nevezani za jezičku sposobnost (kao na primer zakoni fizike) (Čomski 2012). Kako Cvart (1998: 218) navodi, ovaj program zasniva se na principu „minimalnosti“, tačnije na ideji „najkraćeg poteza”, koja zastupa mišljenje da fundamentalno arhitektonsko obeležje ljudskog jezika zadovoljava principe ekonomije i optimalnog dizajna, te zastupa derivativni pristup generisanju jezika. Ovo se postiže primenom principa minimalne komputacije, takozvanom operacijom sjedinjavanja (Merge) kojom se dva već konstruisana objekta spajaju i proizvode novi objekat. Prema Čomskom, ukoliko se vodimo principom minimalne komputacije, prirodno je pretpostaviti da će sjedinjavanje objekata X i Y jednostavno dati kombinaciju XY (Čomski 2012).

Iako su sve navedene teorije naizgled različite, kontinuitet opštih principa generativnog pristupa očigledan je u svakoj od njih. Usvajanje jezika posmatra se kao urođena ljudska sposobnost, a postojanje univerzalne gramatike ne dovodi se u pitanje čak ni u slučajevima gde dolazi do terminološkog razmimoilaženja. Međutim, generativne teorije su prešle dalek put poslednjih pedeset godina, naročito kada je u pitanju pogled na uticaj sredine - ili primarnih lingvističkih podataka - na usvajanje jezika. Iako svakako najuticajnija teorija usvajanja jezika, generativna škola nikada nije bila univerzalno prihvaćena od strane stručne javnosti, dok neke od zamerki upućenih ovom pristupu zadiru duboko u credo generativne sintakse i otvaraju put novim teorijama usvajanja.

Jedna od značajnijih kritika generativnog pristupa tvrdi da se ova teorija bazira na idealizovanoj kompetenciji a ne na stvarnoj jezičkoj produkciji. Paris (2005) smatra kako uzrok problema leži u činjenici da su glavni principi lingvističke teorije nastali na osnovu istraživanja zasnovanih na pisanom materijalu koji su kasnije samo primenjeni na govorni jezik. Drugim rečima, kada generativni lingvisti tvrde da je UG neophodna kako bi premostila jaz između ograničenog inputa i kompleksnih struktura koje su osnova jezičke kompetencije, oni baziraju svoje tvrdnje na pisanim a ne na govornim jezičkim strukturama. Miler i Vajnart nazivaju ovakav tip kompetencije „nad-sintaksom“ (magna syntax), koja po njima uk- 
ljučuje „celokupnu govornu i pisanu tradiciju [...] jezika uključujući konstrukcije koje su aktuelne u govoru i pisanju, konstrukcije koje su aktuelne isključivo u formalnom pisanju, i konstrukcije koje su retke čak i formalnom pisanju" (Miler i Vajnart 1998: 377). Ovo, međutim, nisu konstrukcije koje se pojavljuju u spontanom govoru deteta ili čak odraslog čoveka. Upravo iz tog razloga bilo je potrebno pronaći teoriju koja će pokušati da objasni mehanizme prelaska sa dečjeg na odrasli sistem bez potrebe uvođenja apstraktnih hipotetičkih principa kao što je UG da bi se dokazale hipoteze koje bez istih ne bi ni bilo moguće postaviti. Na ovaj način se ulazi u jedan circulus vitiosus u kome se sve pretpostavke o usvajanju jezika zasnivaju na ideji posedovanja UG čije se postojanje, opet, dokazuje time što bez nje usvajanje jezika na ovaj način ne bi bilo moguće. Popularno verovanje je da je Tomazelov emergenistički pristup u stanju da „popuni praznine” u postojećim teorijama usvajanja jezika.

\section{Tomazelov pristup zasnovan na jezičkoj upotrebi (UB pristup) ${ }^{4}$}

Iako se delo Majkla Tomazela Constructing a Language (2003) posmatra kao svojevrsni manifest UB pristupa, njegov nastanak vuče korene od istraživanja Ronalda Langakera (1988) i Džoun Bajbi $(1985,1995)$ koji postuliraju ideju da se lingvističke strukture u razvoju jezika rađaju iz same jezičke upotrebe - verovanje koje je u direktnom kontrastu sa načelima generativne gramatike. I dok je generativni koncept minimalistički i orijentisan „od vrha na dole” te tako propoveda urođenu algoritamsku funkciju na osnovu koje se izračunavaju sve ostale jezičke vrednosti, UB princip je maksimalistički model „od dna ka vrhu” i zastupa ideju po kojoj se sintaksičke strukture razvijaju iz konkretnih jezičkih primera.

Prema ovoj teoriji, dete započinje put usvajanja jezika negde oko prve godine svog života prepoznavanjem komunikativne namere (Tomazelo 2003: 65) odrasle osobe koja mu se obraća, sto-

4 "Usage-based approach" ili "UB approach". 
ga je i osnovna jedinica usvajanja jezika zapravo iskaz. Ovi iskazi usvajaju se imitacijom uz pokušaje deteta da rekonstruiše ne samo lingvistički input, već i komunikativnu nameru. Samim tim, u prvih nekoliko godina ontogeneze, jezičko znanje deteta predstavlja samo „strukturisan inventar jezičkih konstrukcija“ (ibidem: 7). Ove konstrukcije u početku su najčešće u obliku holofraza - lingvističkih jedinica koje funkcionišu kao čitavi iskazi, npr. kada dete koristi konstrukciju „i Ana“ sa značenjem „i Ana želi sladoled“. Uporedo sa sve većim izlaganjem jezičkom inputu, ove se jedinice proširuju i dete ih zatim raščlanjuje i sastavlja nove konstrukcije oko jednog centralnog elementa (takozvane pivot-sheme npr. i Ana ide, i Ana gleda, i Ana žvaku i sl.). Iako se u ovakvim iskazima mogu naslutiti zečeci gramatike, deca u ranom stadijumu razvoja još nisu u stanju da apstrahuju i generalizuju složena gramatička pravila, već samo povećavaju i proširuju postojeći inventar usvojenih jezičkih konstrukcija. Međutim, usvajajući sve veći broj iskaza, povećavajući frekvenciju tipa i jezičkih jedinica ${ }^{5}$, deca vremenom procesima apstrakcije i generalizacije, a uz pomoć statističkog učenja, iz PLP-a kojima su izloženi sastavljaju shematske iskaze i izvode apstraktna pravila. Ovaj proces se, međutim, ne odvija ujednačenom brzinom, niti može biti govora o jednostavnom „podešavanju parametara", već dete uz pomoć urođenih sposobnosti shematizacije i analogije, a uz pomoć prepoznavanja komunikativne namere i funkcionalno-distributivne analize, putem niza nelinearnih faza kao što su pivot-sheme i konstrukcije zasnovane na čestici (item-based constructions) dolazi do apstraktnih konstrukcija. Na ovaj način se objašnjava očigledna razlika između dečjeg jezika i jezika odraslih.

Još jedno značajno obeležje UB pristupa je da on odbacuje dihotomiju sintakse i semantike koja je toliko bliska Čomskom i njegovim sledbenicima. Generativna lingvistika fokusira se na sintaksu

5 Prema Tomazelu, jezičke strukture rađaju se iz jezičke upotrebe na osnovu frekvencije tipa (type frequency) i frekvencije jezičkih jedinica (token frequency). Frekvencija tipa predstavlja učestalost kojom se izvesna klasa izraza pojavljuje u jezičkom uzorku i direktno je odgovorna za apstrakciju i shematizaciju iskaza, dok frekvencija jezičke jedinice predstavlja učestalost kojom se konkretan oblik pojavljuje u inputu i odgovorna je za proces kognitivnog usađivanja (entrenchment) dotičnog iskaza. 
koja predstavlja urođeno jezičko jezgro (UG) svake jedinke, dok se semantika smatra takozvanom ,jezičkom periferijom” (Tomazelo 2003: 5). Zadatak koji pripadnici ove škole imaju jeste da pronađu apstraktna algoritamska pravila kojima se konstruišu pravilno formirane rečenice. Nasuprot tome, UB pristup prihvata maksimalistički jezički model u kojem su zajedno predstavljeni i apstraktni gramatički šabloni i njihove konkretne leksičke reprezentacije (Eskildsen 2008: 335). Upravo ovaj dualizam omogućava usvajanje jezika kako ga vide emergentisti: u zavisnosti od PLP-a kojima je izloženo, dete pohranjuje konkretne iskaze u svoju bazu podataka, te na osnovu njih - procesima apstrakcije i generalizacije - izvlači šablon, to jest shemu bez potrebe da „obriše“ originalni podatak kao redundantan. Ovo objašnjava postojanje prefabrikovanih kombinacija reči kao što su idiomi i fraze u rečniku dece koja nisu u stanju da generišu slične izraze samo na osnovu generativnog algoritma. Jezik se, dakle, uči primenjujući dve osnovne veštine na lingvistički input: sposobnost tumačenja komunikativnih namera koje predstavljaju simboličku dimenziju komunikacije i sposobnosti pronalaženja šablona, koja je od ključne važnosti za proces formiranja shema i apstrakciju pravila iz dostupnih jezičkih podataka.

Interesantna je činjenica da UB pristup ne negira u potpunosti ulogu urođenosti u procesu usvajanja jezika - samo je sagledava na drugačiji način nego što je to bio slučaj u okviru prethodnih teorija. Lingvisti UB škole smatraju da generativna postavka o genetskoj predodređenosti jezičkih univerzalija nije održiva: samo zato što ljudska vrsta poseduje jezik, ne znači da je to rezultat posebnog jezičkog gena. Tomazelo smatra da su ljudi biološki pripremljeni za usvajanje jezika, ali u vidu nasleđenih kognitivnih sposobnosti koje nisu ograničene isključivo na jezičku komunikaciju. Urođenost dakle postoji, ali to nije generativna urođenost specifičnih lingvističkih struktura, već sposobnosti koje omogućavaju učenje jezika na osnovu raspoloživih podataka.

Iako se na prvi pogled može učiniti da UB pristup nudi objašnjenje pitanja usvajanja jezika, ipak se i ovaj teorijski pravac suočava sa izvesnim brojem problema, od kojih se najčešće spominje takozvani „paradoks početka“, tačnije pitanje kako deca počinju da usvajaju 
jezik. Sam Tomazelo (2000: 63) navodi kako deca nisu u stanju da razumeju i proizvedu jezičke simbole do prve godine života zato što nemaju razvijene mehanizme razumevanja i tumačenja komunikativnih namera koje im omogućavaju da usvoje prve holofraze, a koje se zatim procesima shematizacije i analogije koriste za apstrakciju sintaksičkog znanja. Kritičari UB modela baziraju svoje zamerke na studijama statističkog učenja, pre svega onih vezanih za segmentaciju reči. Prema ovim istraživanjima, problem nemogućnosti akustične definicije fonema koje variraju ne samo od govornika do govornika, već i u govoru iste jedinke (Jošikava 2009) otežava pronalaženje sličnosti između njih i apstrahovanje shema. Noviji modeli jezičkog usvajanja - pre svega ekstremni UB model ${ }^{6}$ i IIM model $^{7}$ - pokušavaju da pronađu odgovor na ovo pitanje eksperimentišući na velikim elektronskim korpusima i CHILDES bazi podataka zastupajući ideju takozvane „bogate memorije”, tačnije tvrdnje da dete prilikom usvajanja jezika pohranjuje u memoriju ne samo sve konkretne primere jezičke upotrebe kojem je bilo izloženo, već i takve detalje kao što su prozodijski elementi i glasovna svojstva govornika (Port 2010: 43-44), te da se sličnosti između konkretnih primera pronalaze retrospektivno, često dugo nakon što su memorisane (ibidem: 14) „strukturalnom analogijom“ između već pohranjenih iskaza (Bod 2009: 752). Na ovaj način izbegla bi se shematizacija na veoma ranom uzrastu i razrešio problem „paradoksa početka“.

\section{Zaključak}

Na samom kraju, još jednom se vraćamo na osnovno pitanje: da li se deca pri usvajanju jezika oslanjaju na urođene kategorije ili ga uče uz pomoć opštih principa i mehanizama generalizacije i apstrakcije? Svaki biolog bi se složio da je ovakva dihotomija veštačka i pojednostavljena: ontogenetski posmatrano od samog začetka na razvoj fetusa utiče kombinacija spoljnih faktora (majčinog zdravlja i nege) i urođenog genetskog obrasca, te je gotovo nemoguće odvojiti

$6 \quad$ Extremely Usage Based Model.

7 Exemplars and Indices Model. 
prirodu od odgoja (Klark 2003: 2). Na isti način pokazalo se da su teorije koje zagovaraju ekstremistički „ili/ili“ pristup sadrže inherentne nedostatke jer zanemaruju bitan skup procesa koji utiču na usvajanje jezika. Upravo je ova svest o neopravdanoj isključivosti pokretačka sila iza promena u okviru generativnog modela, koji počinje da uzima u obzir eksterne faktore kao bitnu komponentu usvajanja jezika, ali i u UB modelu, koji postulira empirijsko učenje na osnovu urođenih sposobnosti. Iako su ove dve teorije usvajanja još uvek daleko od toga da se nađu na pola puta, očigledan je trend otvorenosti za drugačije tačke gledišta, koji utiče ne samo na originalne pravce, već i na nastanak novih metoda i pristupa na njihovim osnovama.

Zaključak do kojeg dolazimo je da odgovor na pitanje usvajanja nije urođenost ili odgoj, već urođenost $i$ odgoj, priroda $i$ spoljašnji faktori. Zadatak budućih istraživanja je da pokažu kakva je tačna priroda ove interakcije i na koji način svaki od elemenata pomaže usvajanju ovog jedinstvenog fenomena.

\section{LITERATURA}

Ajzenbajs 2009: Eisenbeiß, S. (2009). Generative Approaches to Language Learning, Linguistics 47-2, 273-310.

Bod 2009: Bod, R. (2009). From Exemplar to Grammar: A Probabilistic Analogy-Based Model of Language Learning, Cognitive Science 33, 752-793.

Cvart 1998: Zwart, J.W. (1998). The Minimalist Program by Noam Chomsky

- A Review Article, Journal of Linguistics 34, 213-226.

Čomski 1995: Chomsky, N. (1995). The Minimalist Program. Boston, MA: MIT Press.

Čomski 2012: Chomsky, N. (2012). The Minimalist Program and Language Acquisition", govor na ceremoniji dodele počasnog doktorata u SISSA školi u Trstu [online],

http://www.youtube.com/watch?v=GL1GcRrbPm0 [21.02.2013.]

Elman et al. 1996 : Elman, J.L. et al. (1996). Rethinking Innateness: A Connectionist Perspective on Development. Boston, MA: MIT Press.

Eskildsen 2008: Eskildsen, S.W. (2008). Constructing Another Language - Usage-Based Linguistics in Second Language Acquisistion, Applied Linguistics 30/3, 335-357.

Hajms 2011: Hyams, N. (2011).Missing Subjects in Early Child Language.U De 
Villiers, R. i Roeper, T. (ur.), Handbook of Generative Approaches to Language Acquisition, Dordrecht, Heidelberg, London, New York: Springer, 13-52.

Jošikava 2009: Yoshikawa, M. (2009). The „Beginning Paradox“: An Empirical and Conceptual Problem in the Current Usage-Based Model of Language,[online], http://www.academia.edu/1283576/The_beginning_paradox_An_ empirical_and_conceptual_problem_in_the_current_Usage-based_ Model_of_language[05.09.2012 .]

Kerol 2008: Caroll, D.W. (2008). Psychology of Language. Belmont, CA: Thomson \& Wadsworth.

Klark 2003: Clark, E.V. (2003). First Language Acquisition. Cambridge: Cambridge University Press.

Karmilof-Smit 2005: Karmiloff-Smith, A. (2005). Bates' Emergentist Theory and its relevance to the exploration of genotype/phenotype relations. U Tomasello, M. \& Slobin, D.I. (ur.), Beyond Nature-Nurture: Essays in Honor of Elizabeth Bates, Mahwah, NJ: Lawrence Erlbaum Associates, 219-236.

Miler i Vajnart 1998: Miller, J., Weinert, R. (1998). Spontaneous Spoken Language. Clarendon Press, Oxford.

Njuport 2011: Newport, E.L. (2011). The Modularity Issue in Language Acquisition: A Rapprochement? Comments on Gallistel and Chomsky, Language Learning and Development, 7:4, 279-286.

Paris 2005: Parisee, C. (2005). New Perspectives on Language Development and the Innateness of Grammatical Knowledge, Language Sciences 27, 383-401

Port 2010: Port, R.F. (2010). Rich Memory and Distributed Phonology, Language Sciences 32, 43-55.

Semjuels 2000: Samuels, R. (2000). Massively Modular Minds: Evolutionary Psychology and Cognitive Architecture. U Carruthers, P. i Chamberlain, A. (ur.), Evolution and the Human Mind: Modularity, Language and Meta-Cognition, Cambridge: Cambridge University Press,13-46

Snajder i Liljo-Martin 2011: Snyder, W. \& Lillo-Martin, D. (2011). Principles and Parameters Theory and Language Acquisition. U Hogan, P.C. (ur.), The Cambridge Encyclopedia of the Language Sciences, Cambridge: Cambridge University Press, 670-673.

Sugisaki i Otsu 2011: Sugisaki, K.; Otsu, Y. (2011). UG and the Acquisition of Japanese Syntax. U De Villiers, R. i Roeper, T. (ur.), Handbook of Generative Approaches to Language Acquisition, Dordrecht, Heidelberg, London, New York: Springer, 291-318.

Tomazelo 2000: Tomasello, M. (2000). First Steps Toward a Usage-Based 
Theory of Language Acquisiton, Cognitive Linguistics 11-1/2, 61-82. Tomazelo 2003: Tomasello, M. (2003). Constructing a Language: A Usage-Based Theory of Language Acquisition. Cambridge: Harvard University Press.

\title{
Slobodanka Gligorić
}

\section{LANGUAGE ACQUISITION THEORIES: GENERATIVE OR USAGE-BASED APPROACH}

\begin{abstract}
Summary
Language is ability universal to man. This unique form of communication has been a characteristic of our species for some 200.000 years, yet the method of its acquisition is still a mystery to science. The aim of this paper is to present two opposing schools of developmental psycholinguistics: Noam Chomsky's generative approach and Michael Tomasello's usage-based approach, their principal ideas and claims, and to analyse the similarities and differences between the two. Special attention will be devoted to the criticisms aimed at both of these theories, as well as the new schools of thought emerging as a result of such critical reviews.
\end{abstract}

Key words: generative approach, Universal Grammar, UB approach, modularity 